\title{
Animal Testing for Acute Inhalation Toxicity: A Thing of the Past?
}

\section{Da Silva, Emilie; Sørli, Jorid Birkelund}

\section{Published in:}

Applied in Vitro Toxicology

Link to article, DOI:

10.1089/aivt.2017.0037

Publication date:

2018

Document Version

Peer reviewed version

Link back to DTU Orbit

Citation (APA):

Da Silva, E., \& Sørli, J. B. (2018). Animal Testing for Acute Inhalation Toxicity: A Thing of the Past? Applied in Vitro Toxicology, 4(2). https://doi.org/10.1089/aivt.2017.0037

\section{General rights}

Copyright and moral rights for the publications made accessible in the public portal are retained by the authors and/or other copyright owners and it is a condition of accessing publications that users recognise and abide by the legal requirements associated with these rights.

- Users may download and print one copy of any publication from the public portal for the purpose of private study or research.

- You may not further distribute the material or use it for any profit-making activity or commercial gain

- You may freely distribute the URL identifying the publication in the public portal

If you believe that this document breaches copyright please contact us providing details, and we will remove access to the work immediately and investigate your claim. 
Animal testing for acute inhalation toxicity, a thing of the past?

Emilie Da Silva ${ }^{1,2}$, Jorid Birkelund Sørli

${ }^{1}$ Department of Environmental Engineering, Technical University of Denmark, 2800 Kgs. Lyngby, Denmark

${ }^{2}$ The National Research Center for the Working Environment, Copenhagen, Denmark

Keywords: acute inhalation toxicity, animal testing, lung surfactant, regulatory testing. 


\section{Abstract:}

According to REACH (Registration, Evaluation, Authorisation and Restriction of Chemicals), testing for acute inhalation toxicity is required for chemicals manufactured or imported at tonnages $\geq 10$ tons per year.

Three OECD test guidelines for acute inhalation toxicity in vivo are adopted (TG 403, TG 436, and TG 433). Since animal testing is ethically, scientifically and economically questionable, adoption of alternative methods by the European Union and the OECD is needed. An in vitrosystem based on the study of lung surfactant function is introduced. 
In the European Union, the total number of animals used yearly for scientific purposes is over 11 million. Although it is 500,000 (4.5\%) less than in 2008 , this figure remains too high. Toxicological and other safety evaluations account for $8.75 \%$ or over 1 million animals annually(1).

Between 2010 and 2015, 264 chemicals were tested for acute inhalation toxicity (data from echemportal.org) according to OECD Test Guidelines (TG) 403 (183 chemicals) and 436 (87 chemicals). Assuming that a study conducted according to TG 403 (LC 50 protocol) requires 20 animals and that TG 436 uses 18 animals, nearly a thousand animals are subjected to acute inhalation toxicity studies annually in Europe. This number is solely for the testing of chemicals and do not take into account the testing of pharmaceuticals.

According to REACH, testing for acute inhalation toxicity is required for chemicals manufactured or imported at tonnages $\geq 10$ tons per year(2). Three OECD TG are adopted: TG 403 "Acute Inhalation Toxicity", TG 436 "Acute Inhalation Toxicity, Acute Toxic Class Method" and, since the $9^{\text {th }}$ of October 2017, TG 433 "Acute Inhalation Toxicity, Fixed Dose Procedure". For classification and labeling of substances and mixtures, it is recommended to use TG 433 or TG 436 rather than TG 403 as the two first have been adopted with reduction and refinement purposes(3). Further, TG 433 is based on evident clinical signs of toxicity, rather than death as an endpoint, as it is the case for TG 403 and 436(4). However, TG 403 may be necessary when regulatory needs cannot be satisfied with 433 and 436(3). Briefly, to assess acute inhalation toxicity according to these three guidelines, rats (or mice) are exposed nose-only for 4 hours to the test article and observed for at least 14 days after exposure(4-6).

Using animals for toxicological evaluation does not come without challenges. Animal studies are costly and time consuming. As much as 3 to $5 \mathrm{~kg}$ of test article is required for testing(7). In addition, for a classic acute inhalation toxicity test, the experiment protocol has to be submitted for approval by the local ethics committee before the animals are bought and acclimatized prior to testing. Finally, after the 4-hour exposure, the animals are kept for observation for at least 14 days. The estimated turnaround time for carrying out the test is 3 to 4 months(7). Performing animal experiments requires qualified and experienced personnel, adding 
to the cost. Second, following Directive 2010/63/EU, "the methods selected should avoid, as far as possible, death as an end-point due to severe suffering experienced during the period before death"(8). The legislation in some countries, including Denmark, holds that death cannot be the endpoint of an experiment conducted on animals(9). Lastly, the relevance of using rats, or mice, to predict acute inhalation toxicity of a test article in humans is debatable. Lung physiology of rodents differs from humans in several ways. For example, the relative size of inhaled particles compared to the dimensions of the respiratory tract and the breathing frequency are very different in rats or mice compared to humans.

Since animal testing is ethically, scientifically and economically questionable, adoption of alternative methods for acute inhalation toxicity by the European Union and the OECD is needed.

After inhalation, any particle that is small enough will reach the deepest parts of the lungs, the alveolar region. On average, human lungs comprise 500 million alveoli, covering a total surface area of $70 \mathrm{~m}^{2}$. The epithelium of the alveoli is very thin to allow efficient oxygenation of the blood. A layer of liquid, the lung surfactant, covers the epithelium and is essential for breathing. One of its main functions is to reduce surface tension to near zero values in the lungs at the end of expiration. This prevents alveolar collapse and makes breathing effortless(10). Lung surfactant is the initial barrier that any inhaled substance meets. Our hypothesis is that lung surfactant is the first target of inhaled toxicants. Therefore we optimized an in vitro system centered around lung surfactant function monitoring for acute inhalation toxicity testing of inhaled substances(11).

In the so-called constrained drop surfactometer, a drop of lung surfactant is deposited onto a sharp edge pedestal and exposed to the test article(12). A quartz crystal microbalance, placed next to the pedestal, estimates the mass of particles deposited onto the drop(11). The lung surfactant is compressed and expanded in cycles to imitate the surface area variations that occur during normal breathing. The frequency and degree of surface area compression are physiologically relevant. Images of the drop are captured during the exposure and analyzed using the axisymmetric drop shape analysis software to yield surface tensions 
over time(13). Unlike animal experiments, this innovative method is fast. Surface tension measurements can be obtained in real-time and the acute inhalation toxicity profile of a test article can be established within a few days. Moreover, a background in laboratory sciences and an initial training are enough to be able to perform experiments using this method. An additional advantage of the in vitro method is that it is much less expensive. A natural surfactant sold as a pharmaceutical under the name Curosurf ${ }^{\circledR}$ is used. On average, as little as $0.1 \mathrm{~mL}$ of LS at a concentration of $1 \mathrm{mg} / \mathrm{mL}$ (initial concentration of $80 \mathrm{mg} / \mathrm{mL}$ ) is needed for toxicity testing of a test article, i.e. operating cost of about $0.07 €$.

In order to validate lung surfactant function inhibition as an in vitro assay for acute inhalation toxicity, standardization is essential. Improvements are necessary to increase key parameters such as sensitivity, specificity and reproducibility. Even though the system has great potential, it cannot stand alone. Rather it should be used in combination with other in vitro tests (e.g. cell-based cytotoxicity assays) to fully replace animals in acute inhalation toxicity testing.

The method has already been successfully applied to impregnation products(14), inhaled medicines(11) and excipients for drug formulation (article in preparation). In one study comparing toxicity profiles of 21 impregnation spray products in vitro and in vivo, a sensitivity of $100 \%$ and a specificity of $63 \%$ were found. The in vitro method could identify all the products that were toxic for mice to inhale and only three false positive were identified out of the 21 tested products. Furthermore, six of the products were involved in acute inhalation toxicity in humans after accidental inhalation. All of these six products inhibited lung surfactant function in vitro and were toxic to mice. Following the standardization of this method and its validation, industries (chemical, pharmaceutical and cosmetic industries and importers of chemicals $\geq 10$ tons per year) will be able to assess acute inhalation toxicity in a fast, less expensive and ethically sound approach.

\section{Acknowledgments:}

This research was partially supported by the Danish Society for the Protection of Laboratory Animals, AlternativFondet and the Danish Centre for NanoSafety II. 
References

1. European Commission. Report from the Commission to the Council and the European Parliament Seventh report on the statistics on the number of animals used for experimental and other scientific purposes in the member states of the European Union. Brussels; 2013 May.

2. European Chemicals Agency. Guidance on registration. 2016 Nov. Report No.: Version 3.0.

3. European Chemicals Agency. Guidance on Information Requirements and Chemical Safety Assessment Chapter R.7a: Endpoint specific guidance. 2017 Jul. Report No.: Version 6.0.

4. OECD. Guideline 433 on Acute Inhalation Toxicity testing - Fixed Dose Procedure. OECD; 2017 Sep.

5. OECD. Guideline 403 on Acute Inhalation Toxicity testing. OECD; 2009.

6. OECD. Guideline 436 on Acute Inhalation Toxicity testing - Acute Toxic Class Method. OECD; 2009.

7. European Chemicals Agency. Practical guide for SME managers and REACH coordinators - How to fulfil your information requirements at tonnages 1-10 and 10-100 tonnes per year. 2016 Jul. Report No.: Version 1.0.

8. EU. Directive 2010/63/EU of the European Parliament and of the Council of 22 September 2020 on the protection of animals used for scientific purposes. 2010 Oct.

9. Miljø- og Fødevareministeriet. Bekendtgørelse om dyrefors $\varnothing$ g. BEK nr 88 Jan 30, 2013.

10. Enhorning G. Pulmonary surfactant function studied with the pulsating bubble surfactometer (PBS) and the capillary surfactometer (CS). Comp Biochem Physiol A Mol Integr Physiol. 2001;129(1):221-226.

11. Sørli JB, Da Silva E, Bäckman P, Levin M, Thomsen BL, Koponen IK, et al. A Proposed In Vitro Method to Assess Effects of Inhaled Particles on Lung Surfactant Function. Am J Respir Cell Mol Biol. 2016 Mar;54(3):306-11.

12. Valle RP, Wu T, Zuo YY. Biophysical Influence of Airborne Carbon Nanomaterials on Natural Pulmonary Surfactant. ACS Nano. 2015 May 26;9(5):5413-21.

13. Zuo YY, Ding M, Li D, Neumann AW. Further development of Axisymmetric Drop Shape Analysis-Captive Bubble for pulmonary surfactant related studies. Biochim Biophys Acta BBA - Gen Subj. 2004 Nov;1675(1-3):12-20.

14. Sørli J, Huang Y, Da Silva E, Hansen JS, Zuo YY, Frederiksen M, et al. Prediction of acute inhalation toxicity using in vitro lung surfactant inhibition. ALTEX [Internet]. 2017 [cited 2017 Sep 27]; Available from: http://www.altex.ch/online-first 